\title{
Implementing Peer Teaching to Enhance English Students' Language Learning: Kurdish EFL Teachers' and Students' Perspectives
}

\author{
${ }^{1}$ Hemn Adil Karim ${ }^{2 *}$ Aso Ali Mohammed \\ ${ }^{1}$ English Department, University of Garmian, Kalar, Kurdistan Region, Iraq \\ Email: hemn.adil@garmian.edu.krd \\ ${ }^{2}$ Ministry of Education, Kalar, Kurdistan Region, Iraq \\ Email: aso.ali50@yahoo.com \\ *Corresponding author
}

\section{Abstract}

The present study is aimed at introducing the idea of "peer teaching", a student-centered instructional method that can engage students during class and outside the class to reveal common misunderstandings. The study also talks about the guidelines and purposes of implementing the method, and benefits and difficulties of its implementation in English language classes. Data were collected through open-ended questionnaires distributed among Kurdish students majoring English language at University of Garmian and English language teachers at both Garmian and Raparin Universities.

The study findings show that the participants have positive perspectives towards implementing peer teaching in EFL classes to enhance students' learning and language abilities. The teacher participants have neutral responses on using the method in the past. They also mentioned a group of benefits of the model and a number of barriers to its implementation in college classes. Moreover, the student participants welcomed the model and considered it as important as they relied on when they couldn't understand teachers' explanation and missed a session. Likewise, they asserted its usefulness for students who teach and are taught. Finally, students have different views on whether peers' or teacher's teaching more influential is. Most of them rely on peer teaching when necessary, though they think the information students acquire the knowledge from teachers' teaching then use it in peer teaching. While, a small number prefer peer teaching to teacher's teaching.

Keywords: peer teaching, method, enhance, perspective, EFL

\section{An Overview of the Study}


University level students at English departments and programs are always eager to understand their teachers better and put the studied materials into effect. Therefore, they always have many questions for their teachers and peers after lectures in order to discuss the ideas explained but not clear yet or they haven't understood them properly. English teachers may realize the students' problems and what they are stuck with. Thus, they need to diagnose students' real problems which might be lack of engagement and involvement in classroom activities, lack of consistent participation over the semester, lack of collaboration among students, lack of discussions between students, lack of interaction with each other and with the materials, and so forth.

Peer teaching is a model that can be used in EFL classes to engage students during class activities, and make them discuss materials in or outside the classroom, in which students understand the subjects better, and they explain to their fellow students or more accurately to their peers who haven't understood the materials or cannot comprehend teachers' explanations correctly or completely. During the session that can be during the class meeting time, the teacher can work as facilitator and assessor and learners teach learners, or it can be out of class meeting time when learners learn from their peers without their teachers.

Previous researches are small or haven't been conducted to explore the results of implementing peer teaching in EFL classes from teachers' and students' perspectives. The previous researches in the area show that the model can be useful and effective if it is used appropriately, because some teachers and most of the students are not familiar with it and are not urged to practice it.

\section{The Aim and Significance of the Study}

The aim of this study is to introduce the idea of peer teaching, benefits of and barriers to this teaching model, and how and when to implement in English language courses at English departments at colleges, institutes and universities in the entire country to help learners enhance their learning.

The present study is to help Kurdish EFL learners at institutes and colleges to use cooperative way of learning to improve their English language and learning outcomes as well. Since, learners know the classmates' needs rather than teachers and they make lectures more comprehensible as they to some extent have the same level of proficiency. Therefore, this teaching model can be a way to help learners learn better, improve their language, and achieve higher marks. 


\section{The Problem of the Study}

Classrooms are mostly crowded at universities and teachers have to use a way that can serve students' learning well. One of the problems is that teachers cannot normally convey the message to this number of students at a time, so there is a way to help students enhance their learning, which is a learner teaches a learner or a few learners. In addition, some learners cannot easily understand teachers and/or some teachers cannot make lectures comprehensible so peer teaching can a have a key role in bridging the gaps. Thus, teachers can provide English learners with the opportunity of teaching each other inside and outside the class so as to make lectures more collaborative, interesting, and comprehensible.

The study is to sort out the following questions:

○ To what extent do EFL teachers use peer teaching in their classes?

- What are the benefits of and barriers to peer teaching usage from teachers' viewpoints?

○ What are students' perspectives on being a peer teacher and/or a peer learner, and the time of peer teaching?

- What are students' opinions about the influence of teaching by peers and teaching by teachers on EFL learners?

\section{Literature Review}

\subsection{Peer Teaching}

It has been realized that many students learn little from traditional lectures in which teachers follow lecturing. The traditional way of teaching provides little opportunity to students to engage with the subjects, understand central points, and communicate with each other in order to learn better and be an active part of learning process as they have to be.

The first reports on practicing peer teaching in planned situations, which directed by teachers began to appear in the 1960s (Goldschmid and Goldschmid, 1976) cited in (Whitman, 1988: iii) as a result of teacher's dissatisfaction with lectures in which learners were just passive recipients instead of playing active roles. Further, the pioneers 
(Goldschmid and Goldschmid, 1976 quoted in Whitman, 1988: 13-28) categorized peer teaching under two main categories and five types as follow;

1. Near-peers:

a. Undergraduate teaching assistants: are students who recently were successful in the course, and they are useful since they provide a means to supplement large lecture course with small discussion group.

b. Tutors: are also previously successful students, but they teach on a one-to-one basis students who need extra help (i.e. the objective of a tutor is to help improve a student's performance in a specific course).

c. Counselors: are similar to tutors in that they teach on a one-to-one basis. But, unlike teaching assistants and tutors affiliated with a specific course, counselors usually have a more general focus that can provide help with study habits and learning skills (i.e. the focus of counselors is more general).

2. Co-peers:

a. Partnerships: refers to one-to-one relationships in which two students interact as teacher and learner, and

b. Work groups: refers to student groups sharing a common task

The term "co-peer" is used to emphasize the collegial status of students who teach each other are at the same level and the roles of teacher and learner are interchangeable, whereas, "near-peers" teach fellow students who are sometimes more advanced or are close to their level of education. Besides, Whitman (1988: 60) in his study found that learning may occur when students work cooperatively, both peer teachers and peer learners learn, and learning may increase with a blend of situations in which teachers are present and are not present.

Moreover, Topping (1996: 322) describes peer teaching as a process in which students with more abilities help less able students to understand the subject matters in pairs or small groups cooperatively. He further defines peer teaching as a situation when "people from similar social groupings, who are not professional teachers helping each other to learn and learning themselves by teaching" (ibid). Further, in an article "How Using Peer Teaching Gets Students to Think in Classes' Eric Mazur (1997: 982) declares that using the method aids students to think well, not resorting to memorization of materials, and not losing the thread somewhere as they take notes. Peer teaching "is a pedagogy designed to reveal common misunderstandings and to actively engage students in lecture course" (Fagen et al. 2002:206). According to (Butchart et al. 2009), 
peer teaching is "a simple and effective technique that can be used to make lectures more interactive, engaging, and effective learning experiences" (1). Bradford-Watts (2011: 31) also describes peer teaching as "a suite of practices in which peers instruct each other in a purpose-driven, meaningful interaction". In addition, Cortright et al. (2005: 107) propose that "to use peer teaching is to help students be able to interpret, relate, and incorporate new information with existing knowledge and apply the new information to solve novel problems".

As other methods of teaching, peer teaching provides teachers a huge number of choices from various fields of study to implement it in study programs. Dumont (2013: 2) claims that "peer teaching can be used with any topic, concept, or idea, it has appeared in our practice that it was relevant to ask grammar questions language base concepts about writing and levels of language (formal or informal)". In addition to that, the method has been used under various names; Kalkowski, 2001 (qtd in Bradford-Watts: 2011) identifies a group of practices, which are the same to peer teaching including (peer tutoring, partner learning, peer learning, student-teach-student, learning-throughteaching, mutual instruction, and so on" (31). Thus, the method is pedagogically accepted by a number of scholars and has become a part of programs to be implemented in.

To explore the use of peer teaching in different majors including English language field, a number of studies have been done. For instance, in a study (Fagen, et al. 2002) surveyed a great number of teachers who implement peer instruction and other collaborative strategies in their classrooms; the respondents reported a number of challenges such they are skeptical of the benefit of student discussions that take away lecture time, it is difficult to have students teach their peers inside the classroom as the quantity of material to cover in a course often makes it difficult to allocate class time to, and some students are not accustomed to active participation in class, so they feel less comfortable and it is probably difficult to fully engage them in class discussions. On the contrary, they declared that students who are assigned with extra work before attending classes and had worm up activities were successful in their learning and actively engaged in classroom tasks, because discussion for persuading peers about an idea is going to bring about an active atmosphere in class lecturing. Another advantage to consider is that students do not merely learn the resources which they are given as a curriculum. Besides, students learn as they teach (i.e. what is taught is learned). Similarly, Annis (1983) believes that teaching results in better learning than being taught. 
Moreover, in a doctoral dissertation Eryilmaz (2004) studied the effects of peer instruction on students' achievement and attitudes towards physics, found that the results were in favor of peer instruction, whereas, the statistical analysis failed to show a significant difference between the treatment and controlled groups. In addition, studies have been conducted to explore peer teaching method during class meeting time (Cortright et al. 2005) and (Mauricio et al. 2006) found that peer teaching enhanced meaningful learning through mastery of the materials and improved student performance to solve problems they come across. Dangwal and Kapur (2009) also investigated effects of peer-mediated teaching on young children's learning, maintained that they learn more if interact with each other, as peers provide an important context for social and cognitive learning and make sense of their own experience and environment. The same year an action research has been conducted to know the effectiveness of peer teaching on school students by Grubbs and Boes (2009), the study results revealed that the participants believe that the method is effective and more training for tutors boosts its usefulness. Besides, Gok (2012) in his study investigated the effects of peer teaching on college students' learning, motivation, and self-efficacy, found that the students who taught by peer teaching acquired more conceptual learning, and were more self-efficacious, but they were not different from the controlled group who taught by traditional lecture method. Further, Porter et al. (2011) in their article explore whether peer discussion help learners to learn in computing, they reported that $85-89 \%$ of learners benefited from peer discussions during peer teaching implementation.

Additionally, two studies on peer teaching have been conducted recently by two different researchers. Lelis (2017) in her research tries to know how Master's degree students perceive and engage with peer learning activities. The study results indicated that students who performed as a tutor considered the method undeniably positive; however, while being a tutee, students were skeptical concerning the method effectiveness. Yaman (2017) in a multiple case study also studied what happens, if peer teaching will be implemented. She found that peers were interdependence to each other and scaffolding one another for learning, though they experienced some problems such as; not providing reasonable explanations to the peers (i.e. tutees) as they asked about conceptual knowledge and having insufficient knowledge for teaching among some tutors.

Recently, in a study (Zambrano and Gisbert, 2017) explore teachers' explicit representation about peer teaching and teacher collaboration at the start of implementation of a cooperative program to improve reading competence in classroom. 
They found that the teachers' representation was important and their perspectives were positive, and the collaboration is the key to support students' learning. Further, Miquel and Duran (2017) studied peer learning implementation and found that the way is helpful and effective to be introduced to the program in which in-service teachers are trained to develop their teaching in schools.

In language field, a research has recently been conducted by (Bradford-Watts: 2011) exploring peer teaching implementation in an EFL program in Japan. Although, the results showed that students consider becoming teacher to teach peers is difficult. She found that the method helped students improving competence in the subject area, students could understand from peer's teaching more, and helped them to develop autonomous learning skills and be able to cooperate and help each other. In addition, Dumont (2013) in a paper presented in International Conference 'ICT for Language Learning: $6^{\text {th }}$ edition', she investigates using peer teaching in English language learning. After implementing the method for a year, the results indicated that the participants' use of English language increased, so do their self-esteem, engagement in class discussions, and their further understanding.

Active learning and cooperative learning are two other strategies that encompass peer learning and teaching in which there is interdependence of group members in working toward a common goal.

\subsection{Active Learning}

In the last decades, there have been many discussions about the role of student in learning. A wide variety instructional methods, approaches, and strategies have been established to promote the motivation of students in learning. Actively engaging students in class periods is one of the initiatives that teachers have to start with in order to help learners be responsible for their own learning and to have greater motivation to learn and preserve the information they learn. In addition, it is helpful in profound understanding of their subject matters and in their constructive view of the subjects they study in their fields of study. Unlike passive learning, active learning is more practical in language teaching and learning, and students are more motivated towards it, since students willingly do more than listening passively to the teacher. Bonwell and Eison (1991: 2) define active learning as " anything that involves students in doing things and thinking about the things they are doing".

To promote active learning in the classroom (Bonwell and Eison, 1991: 2) suggest some general characteristics that are associated with the use of the following strategies; 
- Students are involved in more than listening.

- Less emphasis is placed on transmitting information and more on developing students' skills.

- Students are involved in higher-order thinking (analysis, synthesis, and evaluation).

- Students are engaged in activities (e.g. reading, discussing, and writing).

- Greater emphasis is placed on students' exploration of their own attitudes and values.

\subsection{Cooperative Learning}

One of the subsets of active learning is "cooperative learning" in which a group of students work on a common task. According to Richards and Schmidt (1985: 135) cooperative learning is "an approach to teaching and learning in which classrooms are organized so that students can work together in small cooperative teams". Further, for Johnson and Johnson (1989: 3) cooperative learning "is a teaching strategy in which small teams, each with students of different levels of ability, use a variety of learning activities to improve their understanding of a subject". It indicates that with cooperative learning students have the opportunities to give and receive information when needed through arguments and discussions to comprehend the ideas and the matters.

\section{Methodology}

The present study is a qualitative study that mainly explores English majoring university level students' and university English language teachers' attitudes towards peer teaching model usage in and out of language classes.

\subsection{Participants and Setting}

The participants in this study are 10 EFL Kurdish native speakers who are asked through open-ended questions to know their perspectives on peer teaching model implementation in English course. The participants are both students and teachers. The students are 5 fourth year students at English department at university of Garmian. They have been studying for four years when they participated in this study. The study took place during their last semester at university. In addition, the teachers are 5 teaching staffs at English Language departments at colleges of education at both universities of Garmian and Raparin. The teacher participants were MA holders, except one who is PhD student, they 
are specialized in general linguistics and applied linguistics, and their teaching experiences are between 4-7 years.

\subsection{Instruments}

The instruments in the study are two open-ended questionnaire (see Appendices A and B) given to two groups of randomly chosen participants. The questionnaires include questions asking to know the participants' attitudes towards peer teaching model implementation in English language classes and out of English language classes among students who teach their peers and be taught by their peers.

Moreover, the participants were introduced to the method in advance, and then the questionnaire distributed among students and sent to teachers. The questions to elicit students' viewpoints were different from teacher participants. Among the student participants, five of them returned back their answers and 5 teachers sent back their responses.

\subsection{Procedures}

The present study collects the data through a survey by distributing two open-ended questionnaires among English language teachers and students to have their opinion on peer instruction in English classes and out of classes (student context) and analyse their ideas qualitatively by the researchers. The participants' names are written as following;

Teacher Participants: T1, T2, T3, T4, and T5.

Student Participants: St1, St2, St3, St4, and St5.

\section{The Findings}

\subsection{Teachers' Perspectives on Peer Teaching Usage in English Language Classrooms}

To know whether teachers have used and use peer teaching model in classes or not and to know the reason behind its implementation or not, this section provides the analysis of the data collected from the open-ended questionnaire (teacher's part: question 1).

The teacher participants' responses to the first question are different. The question asked them whether they have ever used "peer teaching/learner-teaches-learner" in the classroom or not, and why. Teachers (1,3, and 5) have answered yes and were positive and reported that they have used the method many times in their classes, whereas teachers (2 and 4) reported that they have never used. T1 stated that "I have used this method many times in my class since it is one of the practical and fruitful methods in 
teaching. I have done it in many ways such as dividing students on groups, then each group provided with a text to translate it together". Similarly T3 and T5 believe that the method is useful, especially it's cooperative and collaborative rather than being competitive and can help students to work on subject matters in an active way to understand the subjects properly. In addition, T5 added that "while using the method, I often choose a student and assign him/her to be well prepared in a given subject; and then, I provide them acquired time to teach. There're some drawbacks and deficiencies, but it inspires the students better".

Unlike the teachers $(1,3$, and 5), the teachers (2 and 4) haven't used the method yet, because of different reasons. For example, T2 asserted that "because in our educational system, marks define students, so they depend more on teachers not their own skills". While, T4 claims that "I have never used peer teaching due to two main reasons. First, there are too many students in classroom, which makes peer teaching implementation difficult. Second, most students don't have enough motivation to do peer teaching perhaps because of not having information about it or its benefits".

\subsection{Teachers' Perspectives on Benefits of and Barriers to Peer Teaching Implementation}

Teachers' perspectives on the benefits of allowing peer teaching implementation and their viewpoints on the barriers to its implementation may vary from a teacher to another. The second question directed to teacher participants asks whether there are benefit(s) of peer teaching implementation or not. While the third question in the questionnaire tries to elicit information from teachers about the barriers to peer teaching implementation in classes.

To begin with, question two that focuses on the benefits (if any) of peer teaching implementation. The answers vary. All the teacher participants believe that the method has benefits. For example, Teachers (1 and 4) claim that the method makes classes more student-centred. T1 stated that "classes will be student-centred", similarly T4 says that "it improves student-centred teaching".

Teachers $(1,2$, and 5) claim that with peer teaching "students will be more active" T2 stated, and "there will be no passive students in the class" T1 said, meanwhile T5 added that "it helps shy students to participate more".

Another benefit of peer teaching usage is that it helps students to easily learn from each other as (Teachers: 2, 3, 4, and 5) proclaimed. T2 "It helps students understand better 
from each other". Similarly, T3 believes that "students have the same level of proficiency, which helps to understand each other's problems well and teach each other in a more effective way". Besides, T4 said that "students use simpler language or particular discourse, which helps better understanding", and also added that "peers feel less anxious and more comfortable with each other. Therefore, they can openly talk about their learning problems". Further, T5, had a similar idea and said "the students feel more comfortable with peers than with the teacher (though this is not always the case)".

Furthermore, T4 mentioned another benefit that students can use peer teaching especially outside the classroom and out of the class meeting time (i.e. when they have rests). In addition, T5 believes that peer teaching is beneficial for students who teach and are taught as follow:

Benefits for the students that teach ("a. it brings about the moral of integrity and collaboration, b. 'may be funny', but the students will feel the teachers' mood when they talk during the lesson, or not participate in the class, and c. it helps them to be a good potential teacher"). Meanwhile, the benefits for the ones who are taught ("a. it motivates the slow learners to better understand, and $b$. it inspires the careless ones to perform better").

The third question for the teacher participants focuses on what the teachers' viewpoints are on barriers to peer teaching implementation. The responses vary. Teachers mentioned a number of barriers to peer teaching model to be applied in their classes. To illustrate, T1 stated that "there are many barriers to focus. One of them is that the proportions of students are not in favour of following the method as the large number of students in a class needs both time and space to practice it in its own way". Similarly, T4 thinks that "big number of students in the classroom is a barrier, which makes it difficult to implement peer instruction". T5 added that "time insufficiency and the class set ups are usually not appropriate to apply the method, it is also time consuming".

Furthermore, teachers $(2,4$, and 5$)$ believe that students' lack of information on the method, lack of skills, and lack of motivation and interest are barriers to its implementation. For instance; T5 claimed that "students don't have motivation towards such method because either don't have knowledge about peer teaching or are not interested in it".

Additionally, T2 asserted that "the system and student passivity are other two barriers to the method implementation". While, T3 claims that "most of the teachers are not 
familiar enough with the model and don't realize its usefulness". Similarly, T4 adds that "many teachers don't have sufficient information about this instruction method".

Finally, other obstacles are also stated by teachers (4 and 5). For example, T4 believes that "one barrier is the teachers themselves, because most of them see themselves as the authority in the classroom and they are not willing to lose their power". Unlike T4, T5 proclaims that the difficulty of applying the method belongs to some student-related issues as "a. not everyone is skilful enough to assign him/her to the method, b. students may discourage the peers to teach, c. students may respect and follows the peers less, and d. students may talk more during the session".

\subsection{Students' Perspective on Teaching Peers and being Taught by Peers in or Outside the Classroom, and an Appropriate Time to do so.}

In order to provide information on student participants' viewpoints on teaching peers, being taught by peers, and when is necessary to do so, the questions $(1,2$, and 5) will be analysed.

Student participants' responses to questions one and two are similar. The first question asked them (have you ever taught your peer(s) in or outside of class?), and the second question asked whether they have been taught by peers or not. All of them had the same opinion. To illustrate students $(2,3,4$, and 5) answered with one word, which is "yes". Meanwhile, student (1) stated that "Yes, I've taught many of peers throughout previous years outside the class". It shows that St1 has taught peers outside of the class not inside. Moreover, the second question is directed to the student participants to elicit information on whether they have been taught by peers or not. All of the subjects answered with 'yes', except student (1) who said that "Yes, sometimes, when I've got troubles in understanding, I've asked my peers to help me".

In addition, student participants' answers for question five are different. This question attempts to know an appropriate time which is necessary for students to teach peers or be taught by peers. St1 informed that "when the teacher has taught the lecture but yet a student doesn't feel satisfied with his or her understanding, then peer teaching will play an important role". Similarly (St: 3, 4, and 5) think that if they couldn't get teacher's explanation they rely on peer teaching. St3 reported that "Whenever I cannot comprehend a topic and after asking my teacher to explain it again, and I couldn't understand, at that time I ask my peers to teach me". St4 added that "Sometimes students can't understand the teacher in a good way at that time they may understand from their peers better". St5 asserted that "When I couldn't understand my teachers' 
explanation, I ask my peers to help me, and so do they. Therefore, peer teaching is useful for both (i.e. the one who teaches and who are taught), because they can speak and ask freely without being afraid of making mistakes or feeling shy, which is useful for developing their language".

Whereas St2 believes that "It might become necessary in cases of missing or not attending certain lessons or lectures".

\subsection{Students' perspectives on the influence of 'peer teaching' and 'teaching by peers or by teachers'}

The questions three and four in the questionnaire (student participants' part) concentrate on two related issues to find out their perspectives. Firstly, what are the impacts of peer teaching on students in general, and secondly, what could be more influential, teaching by teachers or by peers.

Students' responses to question three were all positive and almost similar. St1 said that "It's really a good way for students, since the one who teaches already knows the problem". Similarly,

St3 stated that "It's very useful because either when you are taught by your peer or you teach your peer, in both cases you are only two students, so you study according to your levels. Thus you will try to make each other understand the subject. When I say according to your level, I mean your teacher when explains things he or she explains for the whole class, so the level of his or her method maybe higher than yours, so the topic will be difficult for you be comprehend".

St4 added that "It's very useful because peers can get benefit from each other, and share different ideas, they may understand each other better, since their ideas, ages and levels are close to each other". Meanwhile, St5 thinks that "it is one of the most influential ways of learning", without adding more clues of why influential it is. Further, St2 confirmed that "it is a useful method, since in which learners have enough comfort to acquire materials and to ask whatever vague is".

The fourth question (Which one is more influential, teaching by teachers or by peers?) has been directed to the student participants in order to have information from their viewpoints. The answers vary. For instance, (St: 1 and 2) are neutral, while (St: 3 and 4) support teachers teaching rather than teaching by peers, unlike them (St5) prefers teaching by peers is more influential. To begin with, St1 stated that "of course both have their own advantages, but I think peer teaching can't be complete without 
teacher's notes and the student's background the information mostly comes from teachers". Similarly, St2 added that:

Each of them has its own type of influence. Of course peers teach what they have learnt from their teachers, but the difference is that not always all of the students learn a certain type and amount of knowledge. Each of the peers share their knowledge and the total shared knowledge are gained through learning from teachers, thus we can say peer teaching is a building, its base is teachers' teaching".

Whereas, St3 asserted that "It depends, to me teaching by teacher is more influential than teaching by peers for almost all my lectures except for poetry, I study it with my friend". St4 also added that "in my opinion teaching by teacher is more influential, but it depends on the way that teacher explains the lecture. If the teacher explains it according to the level of students, it will be more useful". Unlike their responses that they show the reason behind choosing which one is more effective, St5 claims that teaching by peers is more effective in students' learning.

\section{Discussion of Findings}

The next subsections are devoted to present detailed discussion about English language teachers' perspectives on peer teaching implementation in English classes, and what would be the benefits of and barriers to its implementation. In addition, discussions of English language students' perspectives on teaching peers and when suitable it would be to do so are presented. Besides, students' preferences in teaching by peers or by teachers are shown.

\subsection{Peer Teaching Implementation in English Language Classes}

Regarding teachers' responses on using peer teaching in their course, the findings present that they had different responses. More than half of the teacher participants reported that they have used this model of teaching many times in their courses and described it positively. To elaborate, they believe that the model is a way through which students can work cooperatively, collaboratively, and actively on the subjects that need understanding, which are all necessary for English language students.

On the contrary, other participants have never tried it. They believe that due to the country's educational system marks identify who the clever students are, so students always tend to rely on teachers' explanation, not their own peers' skills. In addition, they claim that having a large number of students in class is a reason to prevent teachers from 
implementing peer teaching in class. Students' lack of motivation and lack of knowledge about the model and its benefits is another reason to hinder its implementation.

\subsection{Benefits of and Barriers to Peer Teaching Implementation}

Concerning the teacher participants' responses on benefits of peer teaching, the findings show that all the teachers reacted similarly and mentioned a group of benefits. They claim that the model enhances student-centred teaching, makes students more active, helps students (particularly shy ones) to participate and engage more in classroom activities, and students no longer will be passive during classroom tasks they will be assigned to.

Additionally, they reported another benefit, which is students are provided with better opportunities to work together and understand each other easily as they almost have the same level of proficiency that can allow them to know the problems they confront during their study. They also use simpler language during their peer-to-peer teaching and feel comfortable to work together and talk to each other openly, as they cannot always do so with the teachers. They also added that it can inspire careless and slow students to have better performance and understanding, and helps learners to be good teachers and ready for their future career.

Speaking of the participants' viewpoints on the obstacles facing peer teaching implementation, the teachers had various responses and mentioned different barriers to peer teaching usage in their classes. They informed that the number of students is not helpful to arrange the classroom space and scheduled time to apply the method. Another barrier reported is students' lack of skills, interest, and motivation towards the method, which is probably due to not having knowledge on it. In addition, a teacher participant believes an obstacle to apply the method is that some students may be busy, talk more, discourage peers and not obey them during peer-to-peer sessions. Besides, another participant claimed the educational system and student passivity are two other barriers can be counted on. Meanwhile, some participants proclaimed that teachers' insufficient information about it and considering themselves as the authority in the classroom are barriers to its usage. Although some teachers are afraid of losing their power, Nunan (1999: 12) believes that learner-centred instruction "is neither a matter of handing over rights and power to learners, nor does it involve devaluing the teacher. Rather, it is a matter of educating learners so that they can gradually assume greater responsibility for their own learning". 


\subsection{Peer Teaching and Appropriate Time for Doing it}

This subsection sheds light on student participants' perspectives on the differences between teaching peers and being taught by peers, and when necessary is to do so.

The findings show that the student participants' responses for the first and second questions are all positive and they have the same opinion, but they haven't clarified where they have taught their peers or been taught by their peers inside or outside of the classroom. Unlike all of them, one of the students answered that he has taught his peers outside the classroom, but not during the class meeting time, when teachers are in the classroom. He also informed that he has been taught by peers as he couldn't understand a subject.

Moreover, students reported the time which is necessary to depend on peer teaching (i.e. either teaching peers or be taught by peers), though their answers vary. The results show that there is an agreement incidentally among the students that the appropriate time they decide to depend on peer teaching is when they have trouble understanding teacher's explanation and not satisfied with it. To exemplify, students stated that it is a way of learning from peers, in which the peers add more to teacher's explanation, clarify the points that are not clear, and feel free to ask and discuss the ideas. Finally, a student relies on peer teaching when he is not present in the classroom.

\subsection{Preference in Peer Teaching and Teachers' Teaching}

The findings showed that the student responses are similar relating the students' perspectives on peer teaching effects on students learning, while their preferences in teaching by teachers or peers are different.

Students think that peer teaching is positive and useful for language learners, because of a number of reasons. For instance, students know what kind of problems their peers face as they already went through or lived with. Further, probably students have the same level or study in the same grade. Therefore, they take their level of proficiency into account as they explain the materials to their peers. Besides, with peer-tutoring students are comfortable and ask at their convenience whenever they encounter an ambiguous subject. In brief, students believe that it helps them to comprehend the materials better, so they count it as a useful and influential way of teaching and learning.

Furthermore, the students' preferences to choose the influential way of teaching between (teaching by teachers and teaching by peers), the results showed that they had different point of views. Two of them are neutral as they think that both ways have their own 
influence, though they reported that peer teaching cannot be influential without the information collected from teachers' explanation, it is also obvious that the student who teaches peers has learn from their teachers. Additionally, one of the students supports peer teaching and claims that it is more influential. Unlike them, the other two students are sure and prefer teaching by teachers. They both informed that teaching by teacher is more influential than teaching by peers, especially when the teacher fits his explanation in accordance with students' level of proficiency and language ability.

\section{Conclusions}

A number of concluding points have been reached, in the light of the findings:

- Peer teaching has already been implemented as it is a positive way that students can work cooperatively to understand the English subjects need comprehension.

- The reasons of not using the model are students' dependence on teachers' explanation as a way to get higher marks (as they believe). In addition, a large number of students in classrooms, and students' lack of information on the model.

- The model allows student-centred instruction and increases student engagement in classroom activities.

- It is a way through which students can learn from each other's teaching, since students almost have the same level of proficiency and a common learning problems and learning goals.

- Using peer teaching out of class meeting time has been reported, as a result of not understanding, not being satisfied with teachers' explanations, and not attending the lectures as well.

- Although the model considered as positive and comfortable to apply and to understand subjects better, there were different views on preferring whether peer teaching or teachers' teaching is more influential.

- As there are benefits to peer teaching, there are barriers to its implementation too. For instance, number of students in each classroom, insufficient class meeting time, students' lack of interest, motivation, and skills, and students may misuse the time dedicated to them to teach each other. In addition, teachers don't have sufficient information on the model, and teachers may afraid of losing their authoritative power at the time of implementing the method during lectures.

- The participants' perspectives were positive to a great extent towards the method. Therefore, it has to be applied so that students will get benefit from each other's abilities and peers help their peers to solve the problems they face during their 
learning, as they are in the same situation and can find better ways to learn English language themselves.

\section{Limitations of the Study}

There are a number of limitations of the present study. Chief among them, questionnaires given to many students and teachers, but only five students and five teachers returned and sent back the responses to be analysed by researchers. Furthermore, this small number of participants who participated in the study cannot be easily generalized to all Kurdish EFL teachers and students at English departments in Kurdistan Region universities.

\section{Suggestions for Future Research}

The research paper proposes some suggestions for future studies. The number of study subjects is small; it could be increased in the future research. Further studies might be conducted in other Kurdistan Region universities to explore their attitudes towards peer teaching. In addition, experimental study could be designed with more students and teachers to explore the influence of peer teaching on student learning outcomes and achievements.

\section{Pedagogical Implications}

The findings of the study lead the researchers to recommend these pedagogical implications:

- Peer teaching is a collaborative and cooperative method that engages most of the students, so teachers can help, motivate, and encourage students to use inside and outside the classroom.

- Teachers and students have to be introduced to the method to be familiar with and when to use it.

- Students should be provided with the opportunity to practice the method to help each other in understanding the missing lectures and clarifying unclear ideas to each other using their language ability and style of learning.

- As the results show that peer teaching might be useful for careless and slow in learning students, teachers have to help them use the method more.

- To manage students during peer teaching sessions in the classroom, teachers can facilitate them to have students be engaged and take advantage of the peerteaching session. 
- As findings showed, the method may be used in classes where small number of students will be, and the student seating arrangement should be adapted to the method.

\section{References}

Annis, L. F. (1983). The processes and effects of peer tutoring. Human Learning, 2(1).39-47.

Bonwell, C. C. and Eison, J. A. (1991). Active Learning: Creating Excitement in the Classroom. Washington, D.C.: ASHE-ERIC Higher Education Reports.

Boz Yaman, B. (2017). A multiple case study: What happens in peer tutoring of calculus studies? International Journal of Education in Mathematics, Science and Technology. 120.

Bradford-Watts, K. (2011). Students teaching students: Peer teaching in the EFL classroom in Japan. The Language Teacher, 35(5). 31-35.

Butchart, S., Handfiled, T. and Restall, G. (2009). Using Peer Instruction to teach Philosophy, Logic and Critical Thinking. Teaching Philosophy, 32(1). 1-40.

Cortright, R. N., Collins, H. L. and DiCarlo, S. E. (2005). Peer instruction enhanced meaningful learning: ability to solve novel problems. Advances in Physiology Education, 29. 107-111.

Dangwal, R. and Kapur, P. (2009). Learning through teaching: Peer-mediated instruction in minimally invasive education. British Journal of Educational Technlogy, 40(1). 5-22.

Dumont, A. (2013). Peer Instruction to learn English. A paper presented in the International conference "ICT for Language Learning" $6^{\text {th }}$ edition, Novemebr $14^{\text {th }}-15^{\text {th }}$, 2013. Florence: Italy.

Eryilmaz, H. (2004). The Effect of Peer Instruction on High School Students' Achievement and Attitudes toward Physics. Doctoral Dissertation, Middle East Technical University.

Fagen, A. P., Crouch, C. H., and Mazur, E. (2002). Peer Instruction: Results from a Range of Classrooms. The Physics Teacher Journal, Vol. 40. 206-209. 
Gok, T. (2012). The effects of peer instruction on students' conceptual learning and motivation. Asia-Pacific Forum on Science Learning and Teaching, 13(1). Article 10. 117.

Grubbs, N. and Boes, S. R. (2009). The Effects of the Peer Tutoring Program: An Action Research Study of the Effectiveness of the Peer Tutoring Program at One Suburban Middle School, 16(1). GSCA Journal. 21-31.

Johnson, K. and Johnson, H. (1989). Encyclopedic Dictionary of Applied Linguistics. Oxford: Blackwell Publishers Ltd.

Lelis, C. (2017). Participation ahead: Perceptions of Masters' degree students on Reciprocal Peer Learning Activities 10(2). Journal of Learning Design. 14-24.

Mauricio, J. G., Lujan, H. L., and DiCarlo, S. E. (2006). Peer instruction enhanced student performance on qualitative problem-solving questions. Advances in Physiology Education, 30. 168-173

Mazur, E. (1997). Peer Instruction: Getting Students to think in class. Proceedings of ICUPE. 981-988.

Miquel, E. and Duran, D. (2017). Peer Learning Network: Implementing and Sustaining Cooperative Learning by Teacher Collaboration. Journal of Education for Teaching. 112.

Nunan, D. (1999). Second Language Teaching and Learning. New York: Heinle \& Heinle Publishers.

Porter, L., Lee, C. B., Simon, B., and Zingaro, D. Peer Instruction: Do Students Really Learn from Peer Discussion in Computing? In proceedings of 7 th International Computing Education Research Workshop, 2011.

Richards, J. C. and Schmidt, R. (1985). Longman Dictionary of Language Teaching \& Applied Linguistics ( $4^{\text {th }}$ edition). London: Pearson Education Limited

Topping, K. J. (1996). The Effectiveness of Peer Tutoring in Further and Higher Education: A Typology and Review of the Literature 32 (3). Higher Education. 321-345.

Whitman, N. A. Peer Teaching: To Teach is To Learn Twice. ASHE-ERIC Higher Education Report No. 4. Washington, D.C.: Association for the Study of Higher Education, 1988. 
Zambrano, V. V. and Gisbert, D. D. (2017). Teachers' Expectations of Peer Tutoring Program: Initial Explicit Representation, 20 (2). British Journal of Education, Society \& Behavioral Science. 1-8.

\section{Appendices}

\section{Appendix A}

\section{Teacher Questionnaire}

This questionnaire is designed to collect data for a study; the purpose of doing this research is to explore Kurdish EFL teachers' perspectives towards implementing peer teaching, the benefits of and barriers to its implementation, and its influence on students' learning outcomes. Your responses will be used for data analysis and kept confidential.

\section{$\underline{\text { Part I: Background Information }}$}

1. Degree:

2. Specialization:

3. Years of teaching experience:

$\underline{\text { Part II: Questions for Teachers }}$

1. Have you ever used "peer teaching/learner-teaches-learner" in your classroom? If yes, why and how have you used it? If no, why?

2. What are the benefit(s) of peer teaching?

3. What are the barrier(s) to peer teaching implementation?

Thanks for your participation and contribution 


\section{Appendix B}

\section{Student Questionnaire}

This questionnaire is designed to collect data for a study; the purpose of doing this research is to explore Kurdish EFL students' perspectives towards implementing peer teaching, when to do it, and its influence on students' learning outcomes. Your responses will be used for data analysis and kept confidential.

\section{Part I: Background Information}

1. Gender:

2. Age:

3. Stage:

Part II: Questions for Students:

1. Have you ever taught your peer(s) in or outside the classroom?

2. Have you ever been taught by your peer(s)?

3. How have you found peer teaching?

4. Which one is more influential, teaching by teachers or by peers?

5. When is necessary for students to teach peers or be taught by peers?

Thanks for your participation and contribution 


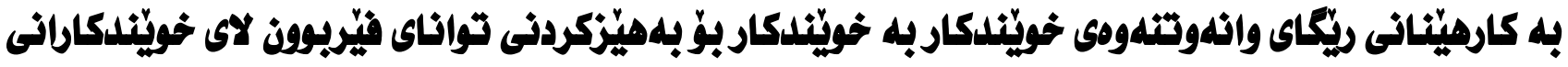

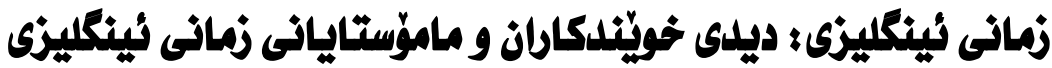

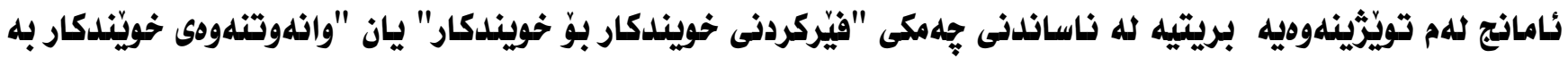

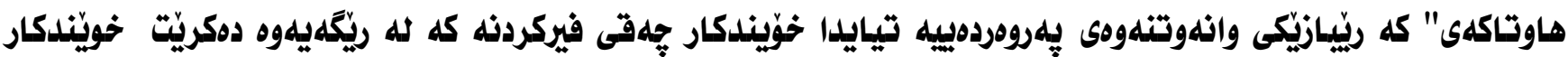

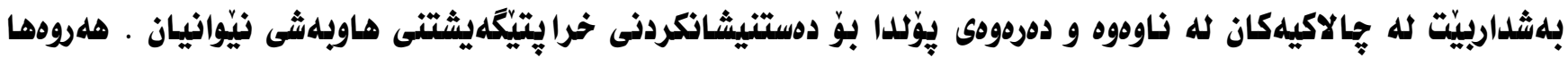

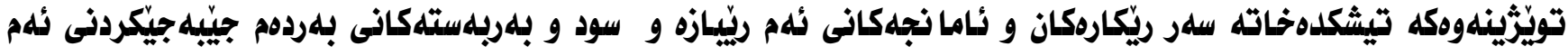

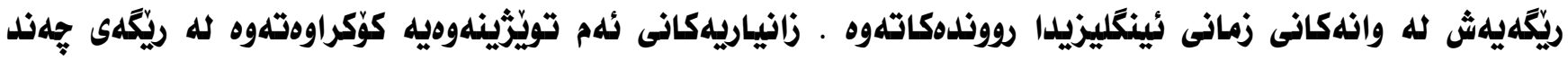

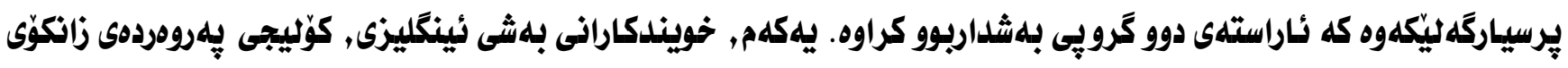

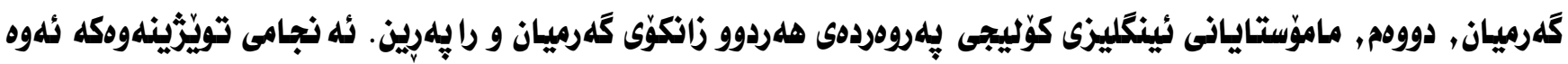

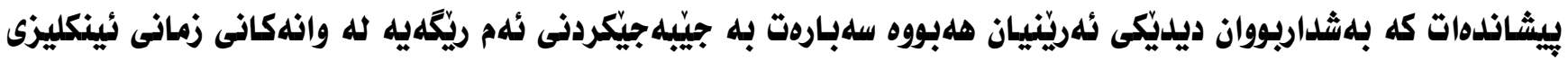

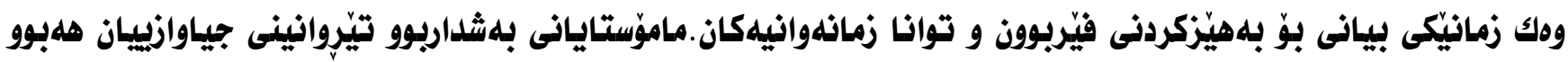

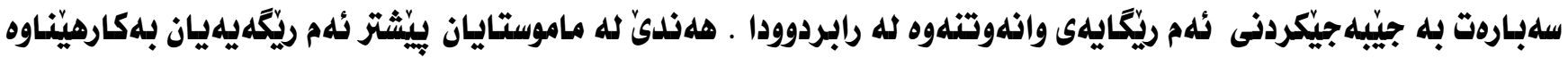

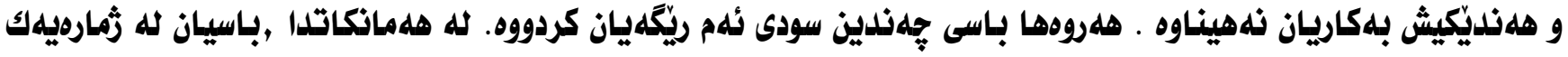

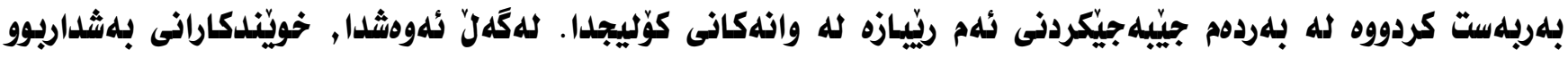

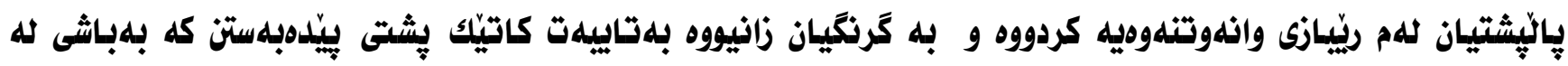

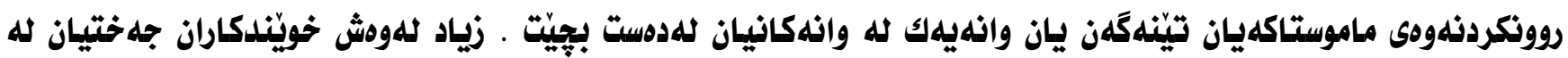

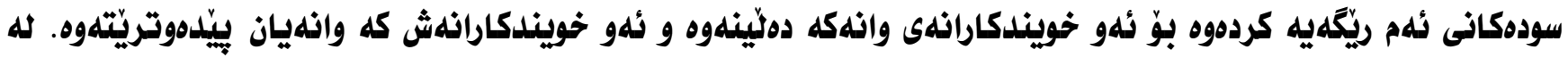

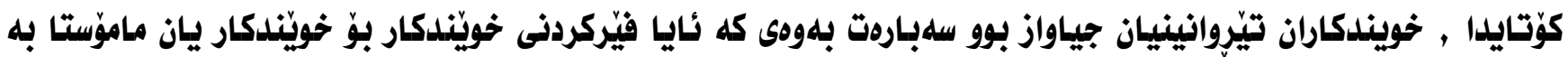

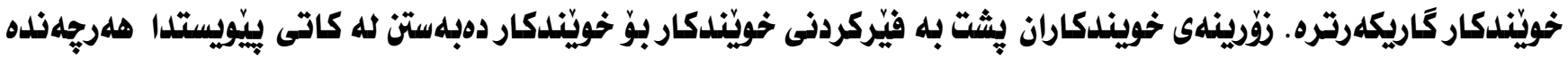

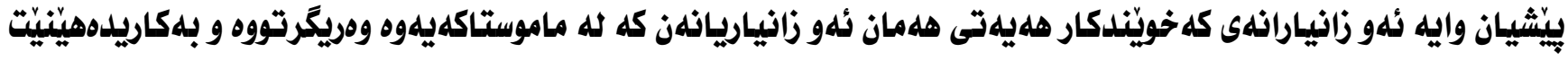

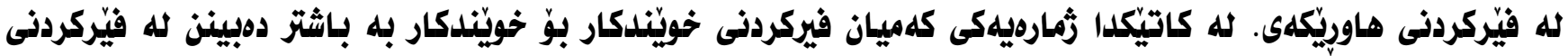

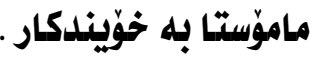

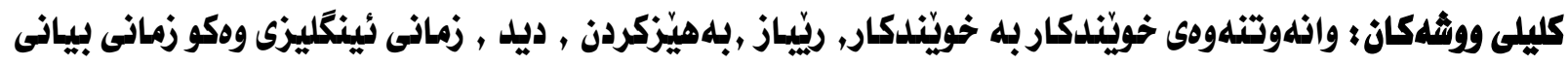


تنفيذ تدريس الأقران لتفزيز تعلم اللفة الإ نجليزية للطلاب : وجهات نظر المعلميز والطلاب كورد في قسم اللفة الانجليزية

هذه الدراسة تهلف إلى تعريف فكرة "تعليم الأقران" كطريقة تعليمية يعتمد على الطالب و يكون طالب فيها محور العملية

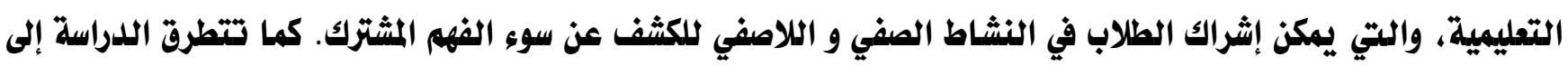

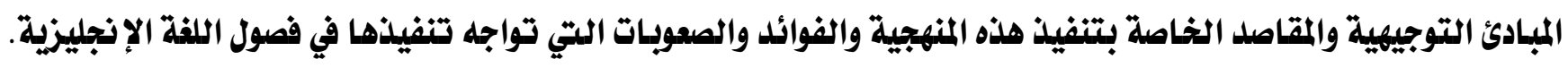
تم جمع البيانات الدراسة من خلال استبيانات مفتوحة تم توزيعها على الطلاب كورد اللين في قسم اللفة الإنجليزية في جامعة

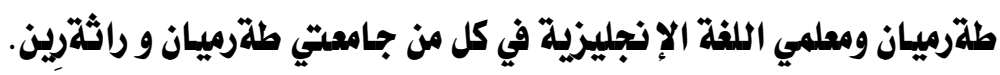

وأظهرت نتائج الدراسة أن الثشاركين لليهم وجهات نظر إيجابية نحو تطبيق تدريس الأقران في فصول اللفة الإنجليزية كلفة أجنبية لتعزيز تعلم الطلاب وقدراتهم اللفوية. وكان للدى المشاركين ردود فعل محايدة على استخدام الطريقة في الماضي. وأشاروا

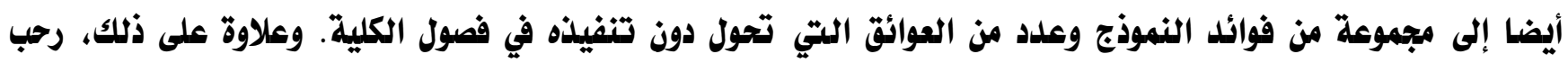

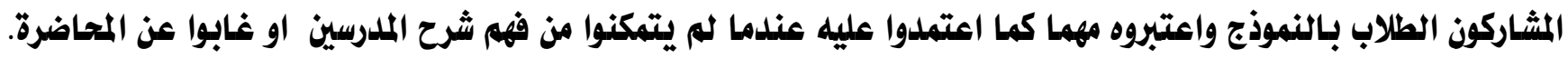

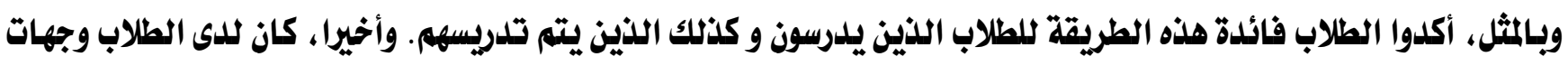

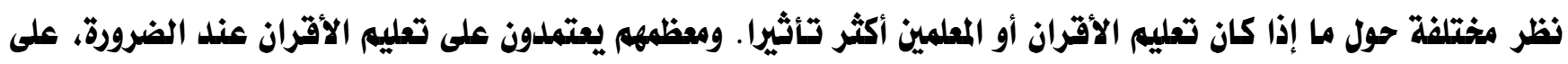

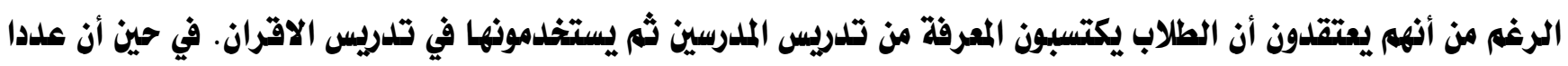
قليلا منهم يفضلون التدريس الاقران على تدريس الملدرسين.

الكلمات المفتاحية: تدريس الأقران، الأسلوب، تعزيز، المنظور، اللفة الإنجليزية كلفة أجنبية 